\title{
CLARIFYING THE CONCEPT OF SALVATION: A PHILOSOPHICAL APPROACH TO THE POWER OF FAITH IN CHRIST'S RESURRECTION
}

\author{
DENIS MOREAU
}

University of Nantes

\begin{abstract}
In this paper, I develop a philosophical clarification of the statement "faith in the resurrection of Christ saves men from sin", using some of the main arguments and hypotheses of my recent book, The Ways of Salvation (Les Voies $d u$ salut, Paris, 2010). I begin with some remarks on the theme of salvation in contemporary language and philosophy. I then sketch a conceptual analysis of the concept of salvation, first in its general sense, then in its specifically Christian one. Finally, I offer a hypothesis on the modus operandi of salvation, or at least of one aspect of salvation as understood by Christianity.
\end{abstract}

\section{THE THEME OF SALVATION IN CONTEMPORARY DISCOURSE}

The concept of salvation still occurs regularly in ordinary language. It also appears, typically without being defined clearly, in a number of contemporary philosophical works far removed from Christianity.

It is striking how commonly the notion of salvation and related words (the verb 'to save', the nouns 'saviour', 'salvage') are used in most European languages. In French, people greet one another with the word "salut," in Italian they say "salve," or "ti saluto," in German they say "salü," (or "heil," "heil dich," in the past). Though people using the word in such situations may not know it, this recalls an ancient practice of wishing an interlocutor 'salvation' upon meeting. For instance, Pythagorean philosophers appear to have greeted each other with the word 'health!' ugiainein, (a greeting also found in the New Testament, at the beginning of The Third Letter of John), and Seneca's letters to Lucilius often begin 
with the formula: "Seneca Lucilio suo salutem dat." The themes of saviour, salvage, salvation, which are etymologically as well as conceptually related to that of salvation are also increasingly common in political discourse (such and such a person is considered the country's saviour), economic discourse (the salvage of a corporation), as well as computer discourse (we save or salvage data). Finally, on a funnier, but no less meaningful note, French supermarkets sell a shower gel called "Axe. Difficult Morning, anti-hangover." The product's packaging states quite clearly that it is intended for people who have a hard time waking up after partying, while the label describes its properties in terms that could come straight from a theology class: "miracle shower gel [...] it will save your morning and bring you back to life after a short and restless night."

Of course, the very frequency with which the concept of salvation is used means that in a certain way it is spent, close to losing its meaning from being used in too many contexts. But it might also be fair to ask whether this frequency of use doesn't echo, albeit weakly, ancient questions, long-standing concerns. In fact, if someone wanted to develop a Christian apologetic on the basis of the contemporary world's language use and dominant concerns, this theme of salvation would probably be an interesting starting point, a 'good hold' as people use the word 'hold' in rock-climbing.

All the more so because, while this notion of salvation retains, in its technical use at least, strongly religious and more specifically Christian connotations, it crops up in a surprising way in the writings of philosophers who are not particularly known for their support of Christianity, or are even quite critical of it.

Nietzsche is a striking if ambiguous example. As everyone knows, he sees himself as a fierce opponent of Christianity. But in several texts, he advocates a system of thought that, like Christianity, will lead to salvation - as long as we interpret salvation in accordance with its etymology, as a healing, the conclusion of a struggle against disease and weakness that yields 'the great health.' ${ }^{1}$ The word also occurs in Jean-Paul Sartre, in the famous last page of his autobiography The Words: "My sole concern has been to save myself - nothing in my hands, nothing up my sleeve - by work and faith. As a result, my pure choice did not raise me above anyone.

\footnotetext{
${ }^{1}$ See, for example, Ecce Homo, "Why I am so clever," I; Thus Spoke Zarathustra, I and II.
} 
Without equipment, without tools, I set all of me to work in order to save all of me. If I relegate impossible Salvation to the prop-room, what remains?"2 Similarly, in a rather mysterious footnote at the end of the section in Being and Nothingness called "Second attitude toward others: indifference, desire, hate, sadism", Sartre adds: "These considerations do not exclude the possibility of an ethics of deliverance and salvation. But this can be achieved only after a radical conversion which we can not discuss here."' Ludwig Wittgenstein, in a text from Culture and Value (1937), for his part, wrote: "If I am to be really saved [erlöst], what I need is certainty, not wisdom, dreams, or speculation [...] For it is my soul with its passions, as it were with its flesh and blood, that has to be saved [erlöst], not my abstract mind."4 And finally, Michel Foucault declares, in a way that is both enigmatic and fascinating, "I know that knowledge has the power to transform us, that truth is not just a way of deciphering the world [...], but that, if I know the truth, then I will be transformed, maybe even saved. Or else I will die. But I believe, in any case, that for me these two are the same." 5

These texts have three things in common: the theme of salvation is, for different reasons, unexpected; we understand, as we read them, that it is an important notion, one that reflects a concern essential to the author who uses it; but neither the context of these texts, nor, often, the entire corpus of their authors, give us a clear idea of how we should interpret 'salvation' or 'being saved'. Such conceptual blurriness, if not legitimate, is at least acceptable in the realm of ordinary language. But it is more problematic in a philosophical discourse that aims at conceptual clarity and rigor. To remedy this situation, I propose here a short clarification of the concept of salvation.

${ }^{2}$ Jean-Paul Sartre, The Words, translated from the French by Bernard Frechtman, Vintage Books, 1981, p. 255

${ }^{3}$ Jean-Paul Sartre, Being and Nothingness, translated and with an introduction by Hazel E. Barnes, Washington Square Press, 1956, p. 534, n. 13

${ }^{4}$ Ludwig Wittgenstein, Culture and Value, translated by Peter Winch, (Oxford: Basil Blackwell, 1974), pp. 32-33

5 “Interview," by Stephen Riggins (1982; Dits et Ecrits, Paris, Gallimard, 2001), II, 1354 


\section{CLARIFICATION OF THE CONCEPT OF SALVATION}

Historically, among the Greeks and Romans, the word salvation first meant the state of being or remaining whole and in good health, "safe and sound." To be saved, then, was to be healed, and salvation, in the practical sense, meant health - not just physical, but also moral and spiritual health. In a more abstract sense, salvation meant both having reached a desirable way of life, as well as the process of attaining it, by being either removed from a situation or freed from a danger that somehow separated us from it. In a general sense, then, salvation can be understood as the return to a desirable former state that had been lost (as when one is saved from a sickness or a shipwreck), the safeguarding of this state against a threat (as one saves one's freedom from a potential oppressor, or one's life from a danger), or, finally, the improvement attaining this state represents. The meaning of the word salvation can, in short, be analyzed into two parts. Understood in its negative aspect, to be saved means to be delivered and freed, rescued and ripped away from a dangerous situation where looms a serious menace. Understood in its positive aspect, to be saved means being granted some good, reaching a state seen as beneficial or desirable, progressing from trials and wretchedness to a state of happiness and fulfilment. Therefore, I think we should find two elements in any soteriology.

(A) A pessimistic or lucid diagnosis of our present situation as one that is painful and dangerous, a state we are inevitably and structurally thrown into, and out of which we must claw our way. An optimistic theory that held that everything is naturally for the best and will continue that way could not be called a soteriology.

(B) A more optimistic assessment of whether it is possible to leave this grievous state behind. If a theory accepts the pessimistic diagnosis of the human condition described in (A), but judges that we are bound to remain in this state of wretchedness, decay, and misery, then it is not describing human existence from a soteriological point of view.

Within the framework of these two elements, we can highlight a number of criteria to distinguish different kinds of soteriologies. For instance, we can distinguish different types of soteriology based on:

(a) Whether salvation is achieved through oneself (auto-salvation) or through someone else, something external to the self (heterosalvation). I will return to this distinction, which plays an essential 
role in differentiating Christian soteriology from most other forms of soteriology developed in philosophical contexts.

(b) The manner of reaching salvation. Individualistic theories hold that it is individuals who reach salvation, and holistic views assume that salvation is achieved collectively, by a group (a community, a nation, a Church, humanity as a whole).

(c) How broadly the class of the saved is extended. Some theories include only a few or a small group among the saved, some include the greater part of humanity, and some universalist or even cosmic doctrines include all of humanity, or even the entire universe, among the saved.

(d) Where salvation will take place: immanent theories hold that salvation is attained in this world, while some reserve salvation for another world.

(e) The nature of the alleged saviour: it can be a god (theo-soteriology), a man or a group of men (anthropo-soteriology), or even something else (extra-terrestrial beings, etc.).

(f) What degree of salvation is attainable: some theories hold that salvation is partial, others that it is total, others integrate the two into a process of salvation in stages or degrees.

(g) The nature of salvation, its content: most often, it is happiness, but even if we leave aside the well-known difficulties in agreeing on a common definition of happiness ${ }^{6}$, there is no logical obstacle to imagining a different content for salvation.

Let us consider, for instance, how the Marxism of the $19^{\text {th }}$ and $20^{\text {th }}$ centuries, interpreted as a theory of salvation (or rather a secularized transposition of a theology of salvation $)^{7}$, fits many of these categories. Marxism combines (a) auto-salvation (it is human beings who save themselves) and (e) anthropo-soteriology: it relies on a group of men (the proletariat, or its educated avant-garde) who hold the function of saviour in a period of transition (until the foundation of a classless society) to achieve a salvation which (c) all men or humanity as a whole share. This is (b) the conclusion of a collective process, which consists in (g) a happiness that is (f) complete and (d) obtained in this world.

\footnotetext{
${ }^{6}$ Cf. Aristotle, Nichomachean Ethics, I, 2

${ }^{7}$ See Karl Löwith, Meaning in History: The Theological Implications of the Philosophy of History (Chicago, University of Chicago Press, 1949), ch. 2
} 


\section{THE SPECIFICALLY CHRISTIAN CONCEPT OF SALVATION}

The New Testament attests that Jesus, whose Hebrew name Yeshoua means 'God saves', was quickly recognized by his disciples as the 'saviour' (salvator, sôter), the one who saves (salvare, sôzô) or brings salvation. ${ }^{8}$ These early Christian texts use different themes, different images, to describe the status of the one who is saved, and the nature of salvation. The saved man is an invalid cured by Christ, a slave he frees, a debtor whose debt he forgives, a man possessed whose demonic bonds he looses, a man condemned whom he pardons, a dead man he brings back to life, etc. ${ }^{9}$

One feature distinguishes Christian soteriology very clearly from those that can be found in ancient wisdom, the philosophical classics (e.g., Spinoza $)^{10}$, Nietzsche, even, when he advises "independents" to "get up on their own"11, and contemporary thought that emphasizes human or personal autonomy. Indeed, for all other soteriologies, salvation is something that man, or in some cases humanity understood collectively, can achieve on his own, by his own actions, by making the best use of his own strengths and natural powers - where the rational powers are often singled out - in a process that is clearly a form of auto-salvation. The end of chapter 9, book IV of Epictetus's Discourses neatly synthesizes this conception of salvation: "Look, you have been dislodged though by no

${ }^{8}$ See, for example, Acts of the Apostles, 4:12, and 13:23; I John, 4:14; Gospel of Luke, 2:11.

${ }^{9}$ For more fully developed typologies, as well as detailed studies on the theme of salvation in different New Testament texts, see, for example, Le Salut Chrétien. Unité et diversité des conceptions à travers l'histoire, ed. Jean-Louis Leuba (Paris, Desclée, 1995); Salvation in the New Testament, Perspectives on Soteriology, ed. Jan G. van den Watt (Leiden-Boston, Brill, 2005); Alloys Grillmeier, "Die Wirkung des Heilshandelns Gotte in Christus" in Mysterium Salutis, ed. Johannes Feiner and Dan Magnus Löhrer (Einsiedeln, Benziger, 1969), vol. III-2, pp. 327-390.

${ }^{10}$ See, for example, Jean Lacroix, Spinoza et le problème du salut (Paris, PUF, 1970). The explicit goal of Spinoza's Ethics is to "lead, as if by the hand, to knowledge of the human mind and its supreme blessedness" (beginning of part II) which is identified as "salvation" ( $\mathrm{V}, 36$, scolie).

${ }^{11}$ Posthumous text cited in Didier Franck, Nietzsche et l'ombre de Dieu (Paris, PUF, 1998), p. 427. Cf. Ecce Homo, "Why I am so wise," $₫ 2$ : "I took myself in hand and I healed myself." We can also remember the taunt "Save yourself" shouted at Christ on the cross according to the Gospels (Matthew 27:40). 
one else but yourself. [...] Turn yourself away to return [...] to freedom [...]. And now, are you not willing to come to your own rescue? [...] If you seek something better, go ahead and continue what you are doing. Not even a god can save you." ${ }^{12}$

Christian salvation, by contrast, is "salvation from elsewhere" ("hetero-salvation"). Man cannot reach it on his own, and it requires an external, divine and supernatural intervention: from a saviour, or else from a revelation - if by revelation we understand a body of knowledge that can neither be found in oneself nor gathered by human intellectual capacities alone, but must be received. The Christian approach to the concept of salvation, then, introduces a notion of, if not passivity, at least receptivity or dependence on an other (or an Other), that is, in the broad sense, a notion of heteronomy.

Salvation as understood by Christianity should therefore be defined as "movement from a negative to a positive state brought about by an external agent [which presupposes] three elements: a terminus, a starting point, and a transforming agent;" 13 or else, "a process whose beneficiaries are moved from a negative situation to a new fulfilled existence by the action of an external agent." ${ }^{14}$ In this case, the external agent is Jesus Christ, who, according to different acceptable translations of a series of Greek verbs used in the New Testament "frees," (eleutheroô), "saves" (sôzô), "delivers" (rhuomai, luô), "tears away" (exaireô) humanity so that it can reach a new way of life.

That Christ is the saviour and that he saves men from sin is an idea that is so obvious to those who accept the Christian faith, that, unlike other concepts also central to Christianity (the trinity, Christ's two natures, etc.), it has never been seriously contested or rejected by any important currents in Christian thought. As a consequence, the great councils that enabled Christians to clarify important but controversial aspects of their

${ }^{12}$ I am following, with some modifications, W. A. Oldfather's translation in Epictetus, The discourses as Reported by Arrian, The Manual, and Fragments, LOEB Classical Library, volume II, pp. 395-397.

${ }^{13}$ Paul-Évode Beaucamp, Supplément au Dictionnaire de la Bible (Paris, Letouzey et Ané), vol. 11, col. 516.

${ }^{14}$ The different components of this definition are taken from Raymond Winling, La Bonne nouvelle du salut en Jésus-Christ. Sotériologie du Nouveau Testament (Paris, Cerf, 2007). 
faith, and thus to discriminate between orthodox and heretical theses, never made it the object of a dogmatic clarification. ${ }^{15}$ The creed of the councils of Nicaea and Constantinople tells us only that Christ came « for

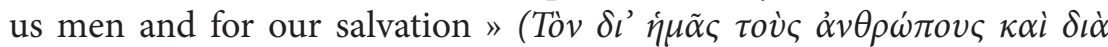

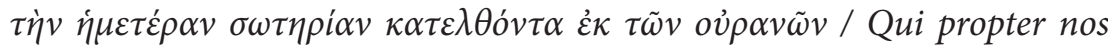
homines, et propter nostram salutem descendit de caelis).

How the process of salvation works, its modus operandi, was thus left so open that it has given rise to a number of speculative accounts, about which it is not always easy to decide whether they are rivals, or whether they bring to light, without fully coordinating or synthesizing their incomplete accounts, different aspects of the concept of salvation. In Latin Christianity, for the last thousand years, the dominant answer to the question of how salvation works was the satisfaction theory proposed by Anselm of Canterbury in the Cur Deus Homo, and developed later, most notably by Thomas Aquinas and later Thomists. ${ }^{16}$ I find this theory quite powerful, and I think that conceptually it is still relevant. But I don't want to ignore the fact that this explanation has become almost foreign, so to speak, or "inaudible" for many of our contemporaries. It has in fact become commonplace, for Christians and non-Christians alike, to reject the satisfaction theory of salvation as "judicial", "sacrificial", "vengeful", and "vindictive". Our contemporaries criticize its characterization of salvation as a "compensatory transaction", and the way it seems to worship pain by concentrating all of Christ's saving work in his passion and the sufferings that accompany it. ${ }^{17}$ Moreover, in focusing so exclusively on

${ }^{15}$ Among Catholics, the "schemata from the preparatory sessions" of the first Vatican council (1869-70) had considered defining redemption, but the texts were neither discussed nor voted on by the council (which was cut short by the Italian army's arrival in Rome). See Jean Rivière, Le Dogme de la rédemption (Paris, Gabalda, 1931), pp. 116-120. There is also a mention (without definition) of the theme of "satisfaction" in a text from the $6^{\text {th }}$ session of the council of Trent.

${ }^{16}$ See Summa Theologiae, III, questions 46-49; see also, for example, Eleonore Stump, "Atonement According to Aquinas" in Oxford Readings in Philosophical Theology, ed. Michael Rea, (Oxford, Oxford University Press, 2009), vol. 1, pp. 267-293.

${ }^{17}$ For this type of criticism among writers who attack Christianity, see for example Nietzsche, The Antichrist, $₫ 41$ : “'how could God allow it!' [Jesus' death] To which the deranged reason of the little community [Jesus' disciples] formulated an answer that was terrifying in its absurdity: God gave his son as a sacrifice for the forgiveness of sins. At once there was an end of the gospels! Sacrifice for sin, and in its most obnoxious 
the passion and death of Christ, this theory doesn't really assign to other aspects of his existence - his incarnation and even more importantly, his resurrection considered in themselves - any significant role in the work of salvation.

Therefore, without rejecting the fundamental importance of satisfaction and atonement in the concept of salvation, it is tempting to look for another explanation, or, more modestly, a complementary explanation of the modus operandi of Christian salvation understood as Christ's freeing us from sin.

\section{AN ATTEMPT TO EXPLAIN THE STATEMENT "FAITH IN THE RESURRECTION OF CHRIST SAVES MEN FROM SIN"}

It's just this type of explanation I'd like to offer. I have tried to take into account an important trend in contemporary theology, which is really a corollary of the current turn away from satisfaction theories: the rejection of an exclusively sacrificial or expiatory theory of salvation, and the desire to see that the thinking that focuses exclusively on Jesus's passion and marginalizes the resurrection stop dominating the discussion. This agenda, which has been, in a way, the height of fashion in European salvation theology since the 1950 's ${ }^{18}$, has been clear in its critical project, clear about what it is rejecting. It has also been clear in its general theoretical aim: "to restore Christ's victory, and return Christ's resurrection to the central place in treatises on redemption it should never have lost"; "[to show that] the resurrection plays a fundamental

and barbarous form: sacrifice of the innocent for the sins of the guilty! What appalling paganism!". And in a Christian author, see for example, René Girard, Des choses cachées depuis la fondation du monde (Paris, Grasset, 1978), p. 269: "God [would] not just be demanding a new victim, he [would] be demanding the most precious, most cherished victim: his own son. This claim has done more than anything else, no doubt, to discredit Christianity in the eyes of men of good will in the modern world. It might have been tolerable to the medieval mind, but it has become intolerable to ours, and has become the stumbling block par excellence for an entire world repelled by the concept of sacrifice."

18 Examples of this tendency born in the inter-war period among Protestant theologians (like Karl Barth) include: François-Xavier Durrwell, Walter Kasper, Joseph Moingt, Jürgen Moltmann (at least in Theology of Hope), Wolhart Pannenberg, Karl Rahner, Bernard Sesboüe, Michel Deneken. 
role in salvation." ${ }^{19}$ But when it comes to the constructive side of the agenda, to specific explanations in support of the general aim, the results have been more problematic, less successful. I am here attempting one such specific explanation of the statement "faith in the resurrection of Christ saves us from sin."

Here, now, is a summary of the argument I have developed to provide a philosophical clarification of this proposition. I will present it in four parts, each one corresponding to a section in my book.

(1) The first section offers a defence of a pragmatic approach to belief: beliefs should be considered not only with respect to their truth value, but also with respect to their effects, how they transform the believer and the world in which he acts. I say "not only...but also" because I don't think we should lose interest in the truth of beliefs, or reject Clifford's principle with its stipulation that the fundamental maxim of the ethics of belief is "It is wrong always, everywhere, and for anyone, to believe anything upon insufficient evidence." But nothing stands in the way of our connecting our interest in the truth of beliefs to a pragmatic investigation of beliefs. We will then supplement our interest in a belief's orthodoxy (how is its content theoretically righteous, speculatively correct) with a further question about its eudoxia (how is it beneficial for the believer who accepts it?). I offer a set of criteria for classifying beliefs from this pragmatic perspective, among which the two most fundamental are the magnitude and the value of a belief's effects. We can thus distinguish between weak beliefs, which have a minimal impact on the believer's life ("beliefs with weak existential implications"), and highly effective ones, which have a significant impact on the life of those who come to believe them ("beliefs with strong existential implications"). We can also distinguish beliefs that produce correct or beneficial behaviour in those who accept them (eupraxic beliefs) from beliefs that produce incorrect or harmful behaviour (dyspraxic beliefs).

(2) Section II focuses on the notion of death. It takes as its starting point the classical view that any proposition about the nature of death (and more particularly of my death) can be an object of belief only,

\footnotetext{
${ }^{19}$ In this order: Henri de Lubac, Le Mystère du surnaturel, ([1965], Paris, Cerf, 2000), p. 20; Bernard Sesboüe, Jésus-Christ dans la tradition de l'Église ([1982], Paris, Desclée de Brouwer, 2000), p. 238.
} 
that positive knowledge or science about my death is impossible. If we accept this, then we are led to ask, even in this life: which among the available beliefs about death are beneficial and which are harmful? In the remainder of section II, I explain, without much original thought, that we spontaneously and naturally believe that death is the end of life, and that in most cases we are afraid of death so understood. As the expression 'fear of death' is a little bland and not always clear, I try to narrow it down by distinguishing different types or different degrees of fear of death. It ranges from the instinctual reaction we share with other animals, fleeing death as a fundamental threat, an annihilation of what we are insofar as we are alive, to highly intellectualized responses like the great artistic evocations of death (Mozart's Requiem, Molière's Don Juan) or philosophical investigations like Heidegger's study of anxiety. The general idea underlying this section is that we are naturally fearful of a death we interpret as the end of life.

(3) Section III shows that this standard belief about death is fundamentally dyspraxic, that is, it leads the believer to behave in ways that are bad and harmful, and which depending on one's lexical preferences, one can call faults, "bad deeds" or "sins". I will call this thesis, that there is a causal connection between the fear of death and sin, "the Lucretius hypothesis" because the idea is expressed, albeit without any detail about the precise nature of the connection, at the beginning of book III of De rerum natura:

... and the old fear of Acheron driven headlong away, which utterly confounds the life of men from the very root, clouding all things with the blackness of death, and suffering no pleasure to be pure and unalloyed (...) Avarice and the blind craving for honours, which constrain wretched men to overleap the boundaries of right, and sometimes as comrades or accomplices in crime to struggle night and day with surpassing toil to rise up to the height of power-these sores in life are fostered in no small degree by the fear of death. For most often scorned disgrace and biting poverty are seen to be far removed from pleasant settled life, and are, as it were, a present dallying before the gates of death; and while men, spurred by a false fear, desire to flee far from them, and to drive them far away, they amass substance by civil bloodshed and greedily multiply their riches, heaping slaughter on slaughter. Hardening their heart they revel in a brother's bitter death, and hate and fear their kinsmen's board. 
In like manner, often through the same fear, they waste with envy that he is powerful, he is regarded, who walks clothed with bright renown; while they complain that they themselves are wrapped in darkness and the mire. Some of them come to ruin to win statues and a name; and often through fear of death so deeply does the hatred of life and the sight of the light possess men, that with sorrowing heart they compass their own death, forgetting that it is this fear which is the source of their woes, which assails their honour, which bursts the bonds of friendship, and overturns affection from its lofty throne. For often ere now men have betrayed country and beloved parents, seeking to shun the realms of Acheron. For even as children tremble and fear everything in blinding darkness, so we sometimes dread in the light things that are no whit more to be feared than what children shudder at in the dark, and imagine will come to pass. ${ }^{20}$

In a number of analyses that I can't repeat here in any detail, I go on to show that the fear of death understood as the end of life leads to a series of evil actions: avarice or greed, gluttony, lust, homicide, disrespect to father and mother, and pride.

By way of example, here is how we can establish a connection between fear of death and avarice, using a text from Karl Marx as support:

That which is for me through the medium of money - that for which I can pay (i.e., which money can buy) - that am I myself, the possessor of the money. The extent of the power of money is the extent of my power. Money's properties are my - the possessor's - properties and essential powers. Thus, what I am and am capable of is by no means determined by my individuality. I am ugly, but I can buy for myself the most beautiful of women. Therefore I am not ugly, for the effect of ugliness - its deterrent power - is nullified by money [...] I am bad, dishonest, unscrupulous, stupid; but money is honoured, and hence its possessor. Money is the supreme good, therefore its possessor is good. Money, besides, saves me the trouble of being dishonest: I am therefore presumed honest. I am brainless, but money is the real brain of all things and how then should its possessor be brainless? Besides, he can buy clever people for himself, and is he who has power over the clever not more clever than the clever? Do not I, who thanks to money am capable of all that the human heart

\footnotetext{
${ }^{20}$ Lucretius, De natura rerum, III, v. 37-90, trans. Cyril Bayley
} 
longs for, possess all human capacities?[...]That which I am unable to do as a man, and of which therefore all my individual essential powers are incapable, I am able to do by means of money. ${ }^{21}$

The text reminds us of the specific function traditionally attributed to money: it is the universal mediator, the converter that makes all things commensurate by translating disparate realities and use-values into the same yard stick (the exchange value). To this classical analysis, Marx adds the idea that the act of buying, understood as an act of appropriation, causes the attributes of the property to be transferred to its owner. By merging the two driving ideas of this Marxist analysis, we can answer the question: in this mode of production and exchange, what is the object whose appropriation money fundamentally allows, and whose properties an owner claims for himself, at least at the level of fantasy?

It is time.

Wage-labour, after all, is the employer's use of his capital to "buy himself" his employees' time as well as the product of their work during that time. A commodity, likewise, is just the fruit of the work-time needed to produce it. It follows that buying and hoarding money (avarice in the strict sense), or objects (in particular, manufactured objects), in other words, being miserly in the broad sense, is really amassing human time, in so far as it is instantiated, and has been, in a certain sense, deposited in those objects. The more money we have, therefore, the more able we are to appropriate other people's time, buying it with wages, or buying it through the mediation of the commodities it has produced, and the more justified we feel in thinking of all this time as potentially our own.

Whether he consumes or saves, and whether his saving is an end in itself or the means to future consumption, the miser doesn't believe that "time is money"; he is rather moved by the belief that "money is time", that in the world in which he acts, having money means being able to acquire other people's time, literally, "saving time" or "buying time".

We can thus interpret the amassing of money as a more or less conscious fantasy promise of an indefinite heap of time, the illusory assurance that our existence will continue indefinitely, and so, as a fantasized attempt to escape our fear of death.

${ }^{21}$ Karl Marx, Economic and Philosophic Manuscripts of 1844. Third Manuscript, tans. Martin Milligan. 
This, then, is how a causal and explanatory connection can be established between the fear of death on the one hand, and avarice or greed on the other. Using a number of different theoretical tools, I try to show in section III of my book that the same connection can be established between fear of death understood as the end of life on the one hand, and gluttony, lust, homicide, disrespect to mother and father, and pride on the other.

Section III's general conclusion, then, is that the common belief about death has the characteristic effect of leading human beings to this type of evil act. The fear of death tends to land us in a kind of existential mediocrity, or, in the worst cases an existential incompetence. In other words, the standard belief about death is fundamentally and globally dyspraxic: it causes us to settle in a negative state that we can also call a state of sin, from which we need to be "saved", right now, in this life.

(4) In the fourth section, I finally turn to the question of salvation. To be saved from the negative state described in the previous section, one might adopt an orthopraxic belief about death - a belief that frees us from the evil acts we commit out of fear of death, and sets in motion a series of intellectual and emotional reactions that improve human existence. Here my remarks turn avowedly Christian: for I believe that the Christian belief that death has been defeated by Christ is such a belief, orthopraxic in the highest degree.

I do not discuss the question of the truth or epistemic reliability of this belief in my book: I have nothing new to say on this subject. ${ }^{22}$ I accept this belief in a hypothetical way, following a method sometimes called philosophical theology. I ask: "If someone believes that Christ is resurrected, thereby signalling to us that death is not in fact the end of life, then what happens?"

All the elements I have discussed so far are falling into place to form a philosophical explication of how Christian salvation works. The belief in Christ's resurrection abolishes the ordinary representation of death as an absolute end, as well as the fearful relationship that follows. ${ }^{23}$ This

${ }^{22}$ On this theme, see, for example, Richard Swinburne, The Resurrection of God Incarnate (Oxford: Clarendon Press, 2003).

${ }^{23}$ Cf. Athanasius of Alexandria, The Incarnation of the Word, 27 (Paris, Cerf, 1973, "Sources chrétiennes" no. 199), pp. 362-365: "Death has been destroyed, and the cross 
belief, then, is able to free us from the morally bad consequences (the sins) of the ordinary representation of death and our reaction to it. Thus, going back to the definition already spelled out, salvation is:

A process whose beneficiaries are moved from a negative situation... That is, humanity's situation as depicted in section III: "led astray" by the ordinary representation of death, and with a propensity to morally undesirable acts.

... to a new fulfilled existence...A man who no longer acts as described in section III has settled into a better realm of existence, one that is qualitatively superior to his former existence, not only because he is now rid of certain negative features, but also because he finds himself in a new set of circumstances conducive to leading a new life, one where dynamisms and capacities that could not be developed in his former existence can flourish. Ancient authors summarized it this way: "Christ killed the death that was killing man"; "he cast death's tyranny out of our nature completely by rising from the dead." ${ }^{24}$

... by the action of an external agent. Salvation is brought about by the power of the belief in Christ's resurrection. From an objective or historical standpoint, the external agent, the saviour, can be identified as Jesus Christ. If, on the other hand, we focus on the information contained in the proposition "Christ is resurrected," then the external agency is a revealed body of faith. For this proposition cannot be deduced from natural principles of human knowledge, nor can it be demonstrated a priori, and it is no doubt quite different from an ordinary piece of historical or experiential knowledge. It must therefore be a "revelation", which means that it presents for belief a body of knowledge that does

represents the victory won over it. It has no strength left, it is really dead. [...] Ever since the Saviour resurrected his own body, death is no longer frightening. All those who believe in Christ [...] really know that if they die, they do not perish but live."

${ }^{24}$ Melito of Sardis, Peri Pascha (Paris, Cerf, 1966 "Sources chrétiennes", no. 123), pp. 96-97; Nicholas Cabasilas, The Life in Christ, III, 7 (Paris, Cerf, 1989-1990 "Sources chrétiennes" no. 355 and 361), p. 243. The text of this $14^{\text {th }}$ century Byzantine author deserves to be quoted more completely: "Thus, while men were cut off from God in three ways - through nature, through sin and through death - the saviour allowed them to meet him perfectly [...], by removing one by one all the obstacles that kept them apart: [he removed the obstacle of] nature by sharing in humanity, the obstacle of sin by dying on the cross, and the last obstacle, the tyranny of death, he completely expelled from our nature by rising from the dead." 
not and cannot come from "me", but is given from elsewhere. Of course it belongs to the world, it appears in it, but from a source that is divine, or claimed to be so.

To use a different language: all the analyses I've developed so far now make it possible to explain the proposition "faith in the resurrection of Christ frees men from sin". If these earlier hypotheses are granted, then faith in the resurrection of Christ will, or should, set in motion in the individual who accepts it a series of intellectual and emotional transformations that improve his existence. If, as I have argued, the central problem of human life, what leads us astray and ruins our lives, is precisely a certain fearful relationship to death understood as the end of life, then the belief that death has been vanquished - a belief central and unique to Christianity ${ }^{25}$ - must be an excellent way to reach salvation - where salvation is understood as an improvement of existence that begins in this life, not in its eschatological sense (though, of course I don't reject that sense of the word).

\section{CONCLUSION}

In conclusion, let me make four qualifications to the thesis I am defending.

(a) I am not, of course, claiming that we are saved through knowledge, and that salvation is available only to the "experts" who think seriously about how salvation works. That would be Gnosticism, and I am not a Gnostic. It is faith that saves in my view, and it is "enough", so to speak, to believe that Christ is resurrected to enter into the process of salvation I describe. Someone who thinks seriously about the problem just adds an explanation of how the dynamics works, or tries to make the process intelligible.

(b) The thesis I am defending does assert that salvation or "justification" is brought about by faith, or, more precisely, by faith in Christ's resurrection with its message that death has been defeated. ${ }^{26} \mathrm{I}$ am here using the world faith in a strong sense, the sense of the credere in

\footnotetext{
${ }^{25}$ See the famous claim by Paul of Tarsus in I Corinthians, 15:14: "if Christ had not been raised, then our proclamation has been in vain and your faith has been in vain." (New Revised Standard Version)

${ }^{26}$ Cf. Saint Augustin, Contra Faustum, 16, 29, Migne PL, vol. 42, col. 336 : "The very resurrection in which we believe justifies us."
} 
Deum, of strong conviction, a deep and sincere adherence that causes noticeable changes in the believer's interactions with the world. It is faith used in this sense that has certain consequences for the believer's salvation in my remarks above. It is again, faith used in this strong sense that contemporary authors call performative: "the Christian message was not only 'informative' but 'performative"; "is the Christian faith [...] 'performative' for us - is it a message which shapes our life in a new way, or is it just 'information' which, in the meantime, we have set aside and which now seems to us to have been superseded by more recent information?" ${ }^{27}$ If, by "performative" (in the broad sense) ${ }^{28}$ we understand the property whereby certain beliefs not only represent a state of affairs ("information"), but also produce a change by forming or transforming other beliefs and behaviours, then we can indeed speak of the saving character of performative faith in Christ's resurrection: the belief that death has been defeated has the characteristic effect of producing salvation. Being freed from sin - that is, being less tempted, better able to resist temptation, committing fewer or even none of the morally reprehensible acts described above - flows directly from the radical modification in the meaning of death that comes from accepting the belief in Christ's resurrection.

c) On the other hand, in this defence of salvation through faith, I do not mean to commit myself to a specific position in the age-old (though nowadays mostly becalmed) theological debate about the respective roles of faith and works (i.e., individual actions) in salvation. Even if my thesis can nominally evoke the sola fide of the Reformation, since it gives faith the essential role in the production of salvation, it is in fact closer to the position generally thought of as the Catholic one: where the emphasis is on how man is brought into a situation where he can act well, and, using his freedom correctly, (subjectively) appropriate the salvation Christ brings (objectively). In this light, justification becomes the fact of finding oneself in a new practical context, one where obstacles and obstructions to right action no longer bind us when we act, so that it becomes possible for us to be just. On this interpretation, then, justification is more

${ }^{27}$ Joseph Ratzinger/Benedict XVI, Encyclical Spe Salvi, $\$ 2$ and $\$ 10$.

${ }^{28}$ In the narrow sense (that of J.L. Austin) used in the philosophy of language, only public utterances (and not mental states) that actualize what they describe, or "do what they say", are called 'performative'. 
a journey than a consequence of faith in the resurrection that is acquired once and for all; it is not so much a state in which we find ourselves, as the lifelong tension required for becoming just. Collectively, it is less an event we can describe as having happened, than the process in which, according to Christianity, human beings have been involved since the discovery of the empty tomb. The idea that what leads to salvation is revealed implies a certain receptivity, or even passivity, as the intervention of a God or saviour implies heteronomy. But, it turns out, none of these are incompatible with the individual's having, or needing to have some personal agency in the process of his salvation, that is, with the possibility that the individual's actions will have the character of an auto-salvation. Receptivity and passivity are the starting point, necessary conditions for a new mode of action that an individual can't adopt on his own.

d) Finally, I want to say more about what it means for this discussion of Christ's saving action to shift the focus from the passion to the resurrection - something scholastic theology often saw as nothing more than a happy ending (it's always better when the good guy wins) or else a "miracle" meant to elicit or strengthen faith. ${ }^{29}$ First of all, the shift of focus does not imply that the darkness of Good Friday was useless or superfluous, that Jesus's dying on the cross after a degrading agony was irrelevant, or that nothing essential would be missing if he had died peacefully in his bed before being resurrected a few days later, or even more to the point, if he had proclaimed his victory over death without dying himself. First, as theologians in the first few centuries explained in their arguments against the docetist heresy, the reality of Christ's resurrection and humanity require the reality of his death. Second, the passion insofar as it is sorrowful and negative, and the resurrection, are like two facets of the same event - an event that brings salvation ${ }^{30}$ and

${ }^{29}$ See, for example, Cajetan's commentary on Saint Paul (On Romans 4:25) Epistolae Pauli et aliorum apostolorum [...] juxta sensum literalem enarratae [1531].

${ }^{30}$ Ultimately, Thomas Aquinas doesn't disagree: "as to efficiency, which comes of the Divine power, the Passion as well as the Resurrection of Christ is the cause of justification." Summa Theologiae III, question 56, article 2 ad 4. This same question in the Summa parcels out each one's role by distinguishing two aspects in the "complete" concept of redemption: the passion and death of Christ cause the forgiveness of sins by providing satisfaction, while the resurrection institutes a new life. In every case, finding "the correct dose" of passion and resurrection respectively seems to be one of the central concerns of Christian soteriology. 
revelation - which can only be fully understood by focusing alternatively on one or the other of its facets. In its initial phase, this event reveals that salvation is not obtained easily; it is not obtained through the means usually promoted in the world (power, riches, honour, will to dominate), through violence, the desire to punish or to seek vengeance. Christ's passion shows that the road to salvation is hard, and that the fight against evil and everything that leads to it is sometimes painful and can require great sacrifice. The passion reminds us that "there is here an ordered sequence that Christ himself followed: first the passion, then the glorification. [...] As long as our life here on earth lasts, suffering and death come before joy and resurrection." ${ }^{31}$ As the theologians say, it was "appropriate," from this point of view, that Christ should die in the agony of the cross. However, the passion (and this includes its role in salvation) can be fully understood only in the light of the later event that gives it meaning. A story in which Jesus was only crucified would have a completely different meaning. Or it might not have any meaning at all, like a symbol of the absurdity and cruelty of the world. So, following Karl Barth, I want to warn those who think seriously about Christian justification and salvation against the Nordic Melancholy of a (good) Friday theology, abstractly focused on the cross alone and forgetful of Resurrection Sunday.

The seriousness with which we insist on the starting point of justification is a good and necessary thing, that is, on the fact [...] that we can only go in one direction: from the death [of Jesus] on the cross to his resurrection. And so we must consider first what is past, that is, our death which he suffered, then what is future, that is, the life he received. [...] But we must see to it that this seriousness - there are examples of this both in Roman Catholic and also in Protestant circles - does not, at a certain point which is hard to define, become a pagan instead of a purely Christian seriousness, changing suddenly into a "Nordic morbidity", losing the direction in which alone it can have any Christian meaning, suddenly beginning to look backwards instead of forwards, transforming itself into the tragedy of an abstract Theologia crucis which can have little and finally nothing whatever to do with the Christian knowledge of Jesus Christ.

${ }^{31}$ Hans Urs von Balthasar, Theodramatik, 5 vol., Fribourg-Einsiedeln, Johannes Verlag, 1973-1983, vol. 4 
[...] The knowledge of our justification as it has taken place in Him can not possibly be genuinely serious except in this joy, the Easter joy. ${ }^{32}$

Finally, I do not for a moment claim that this explanation of how salvation works is the only valid one or that it excludes all others. It is, for instance, perfectly compatible with the satisfaction or atonement theory. Ultimately, I think that the best description of the Christian conception of salvation is this: "Christ's incarnation, his life and acts, his passion, death and resurrection, are what make salvation from sin possible." Of course, one could say that all this constitutes just one event of salvation, the "Jesus Christ event". But as soon as we try to explain how this salvation really works, we end up distinguishing different explanatory frameworks; some that focus more on the incarnation's saving power as is the case with so-called deification-theories, others like satisfaction theories, that focus more on the passion. As a philosopher, and following in the footsteps of some of Saint Paul's texts ${ }^{33}$, I have wanted to draw attention to the soteriological value of faith in the resurrection. ${ }^{34}$

32 K. Barth, Die Kirchliche Dogmatik (Zurich, Evangelischer Verlag Zollikon, 1932-1967) IV, vol. 1, ch. 14, \$61, 2

${ }^{33}$ For example, Romans 10:9: "if you confess with your lips that Jesus is Lord and believe in your heart that God raised him from the dead, you will be saved." (New Revised Standard Version) On this point, see Stanislas Lyonnet: "La Valeur sotériologique de la résurrection selon saint Paul” in Christus victor mortis, Gregorianum 39-2 (1958), pp. 295-318.

${ }^{34}$ Because I want to stick to a philosophical approach, I do not tackle the theme, in all respects difficult, of original sin. The thesis that I defend retains this claim characteristic of Christian theology: between death and sin, there is a causal relationship in the strong sense of productive causality. But it reverses the direction in which the theological tradition, following a possible interpretation of the texts of St. Paul (eg. Romans, 5, 12) has most often considered this relationship: sin (of Adam ) would have produced death (the mortality of man, the "finiteness") that is to say, strictly speaking, the fact of dying and, in an analogical sense, the "spiritual death" brought about by the breakdown in the relationship with God. If we take "death" in the strict and biological sense, achievements of modern science seem difficult to reconcile with this view (as, in all cases, the theme of a unique and temporally determined peccatum originale originans). My interpretation avoids this problem, considering that sin, as a situation, and from there the sins, as actions, follow from mortality as it is spontaneously understood as a fundamental characteristic, both biological and existential, of humanity. The point is not to identify "sin" and "finiteness", but to show how sin stems from a form of spiritual negativity inherent to a certain understanding of finiteness, probably de facto inevitable, but not insurmountable. 
I don't think that anyone can be certain with categorical certainty, that the proposition "Christ is risen from the dead" is true. Accepting it will always imply an irreducible element of faith, something like a bet that answers the existential question "what may I hope?" as much as the historical one "what can I know?". But if this proposition is true, if death really has been conquered by a fully human person, this implies an unprecedented existential transformation, whose full array of consequences, in my view, contemporary philosophers, including those who have paid a lot of attention to the relation between life and death (phenomenology, for instance, in Heidegger) have not analyzed. I have tried here to sketch out a few of those consequences, while at the same time suggesting that there is a real existential benefit to the belief that Christ is risen from the dead, in betting, as Pascal understood the word, that he is really risen. 